UDC 582.711.714:581.45/.46:547.913:54.062:54.021

DOI: $10.15587 / 2519-4852.2021 .249276$

\title{
COMPARATIVE STUDY THE ESSENTIAL OIL COMPOSITION OF FLOWERS AND LEAVES OF CRATAEGUS MONOGYNA L.
}

\author{
Natalia Sydora, Olena Konovalova, Svetlana Zuikina, Kateryna Semchenko, Anna Rudnyk, \\ Iryna Hurtovenko
}

The aim of the work was to obtain essential oil from the leaves and flowers of the genus Hawthorn Crataegus
monogyna L. and study its component composition to justify the possibility of expanding the use of this herbal
drugs in medicine.
Materials and methods. The leaves and flowers of Crataegus monogyna L., which were used to obtain essential
oil, were harvested in the western region of Ukraine in 2019. The quantitative content of essential oil in the herbal
drugs was determined by hydrodistillation. By used chromato-mass spectrometry method determined the com-
ponent composition of essential oil of leaves and flowers of Crataegus monogyna L. The obtained spectra were
compared with the library of mass spectra NISTO5 and WILEY 2007 with a total number of spectra over 470000 in
combination with programs for identification AMDIS and NIST. Results. The essential oil of leaves and flowers of Crataegus monogyna L. was obtained and its quantitative content was determined, which was $0.15 \pm 0.02 \%$ for flowers and $0.11 \pm 0.03 \%$ for leaves. By used chromato-mass spectrometric method in the essential oil of flowers of Crataegus monogyna L. revealed 37 compounds, leaves - 33. In the essential oil of flowers found monoterpenoids, the content of which was $0.44 \%$ of the total, triterpenoids $7.17 \%$, aromatic compounds $12.61 \%$. In the essential oil of leaves were found monoterpenoids $37.8 \%$, aromatic compounds $10.25 \%$, norterpenoids $3.62 \%$, sesquiterpenoids $4.02 \%$, diterpenoids $2.17 \%$, triterpenoids $5.08 \%$. Conclusions. Due to the defined component composition of the essential oil of flowers and leaves of Crataegus monogyna L., we consider its use to create drugs of external action for the treatment of skin diseases of various etiologies caused by staphylococcal and fungal microflora

Keywords: hawthorn, leaves, flowers, essential oil, quantitative content, chemical composition

How to cite:
Sydora, N., Konovalova, O., Zuikina, S., Semchenko, K., Rudnyk, A., Hurtovenko,
of flowers and leaves of Crataegus monogyna L. ScienceRise: Pharmaceutical Sci
4852.2021 .249276
(C) The Author(s) 2021
This is an open access article under the Creative Commons CC BY license hydrate

\section{Introduction}

Considering the reduction in Ukraine the base of official plants, under the influence of various factors, both environmental change and urbanization, the effective processing of herbal drugs becomes especially important. Hawthorn - Crataegus monogyna L. is an official plant in Ukraine and European countries, and its herbal drugs "Hawthorn fruit", "Hawthorn leaves and flowers" are included in the State Pharmacopoeia of Ukraine (SPhU) and the European Pharmacopoeia (EP) $[1,2]$. Today, this herbal drug is used as a source of phenolic compounds, mainly flavonoids (rutin, quercetin, hyperoside) to create drugs with antihypertensive and antiarrhythmic effects [3, 4]. Preparations based on hawthorn herbal drugs are used both alone and in combination with other drugs and more pronounced antihypertensive activity is characteristic for hawthorn fruit extracts $[5,6]$. Alcoholic extracts of flowers are used in tachycardia and as coronary agents [7]. Known antioxidant properties of phenolic extracts of fruits and leaves of Crataegus monogyna L. [8, 9]. Alcoholic extract of Crataegus monogyna $\mathrm{L}$. in the experiment showed the ability to affect the level of lymphocytes and reduce the risk of bleeding in the postoperative period $[10,11]$. Hawthorn belongs to the genus Hawthorn (Crataegus L.) of the family Rosaceae L. [12]. It is one of the most numerous genera of this family, numbering more than 1500 species [13]. Representatives of the section Oxyacantha Loud., which includes Crataegus monogyna L., have rare inflorescences, sawtooth-cut leaves, red fruits with 1 stone [14]. In the wild, the plant is found in Western Ukraine and successfully cultivated [13].

There is almost no information in the literature on the study of other classes of biologically active substances, in particular, compounds that are part of the essential oils of flowers and leaves of Crataegus monogyna L. In herbal drugs of other species of the genus Hawthorn, including members of the section Oxyacantha Loud., we are identified volatile compounds that exhibited antimicrobial, bactericidal and anti-inflammatory properties, which was proved experimentally [4, 14]. Given that microorganisms can form different strains that are resistant to existing drugs, the search for new plant sources of biologically active compounds with antimicrobial, bactericidal and fungicidal action in modern realities has not lost its relevance. 
So, the aim of the work was to obtain and in-depth study of the component composition of essential oils of leaves and flowers of Crataegus monogyna L. to expand the range of uses of this herbal drugs and create new drugs based on it.

\section{Planning (methodology) of the research}

The stages of the research of herbal drugs materials Crataegus monogyna L. are shown in Fig. 1. with a solution of potassium hydroxide $(0.1 \mathrm{~mol} / \mathrm{l}) .0 .5 \mathrm{ml}$ of phenolphthalein solution was used as an indicator. After the resulting solution was titrated with potassium hydroxide solution $(0.1 \mathrm{~mol} / \mathrm{l})$ until a pink colour that does not disappear for 15 seconds. The acid number was calculated by the formula:

$$
I_{A}=\frac{5.61 \cdot n}{m},
$$

Stage 1. Prepar herbal drugs (leaves and flowers) Crataegus monogyna L. for research

Stage 2. To obtain the essential oil of leaves and flowers of Crataegus monogyna $\mathrm{L}$., determine its conte herbal drugs

Stage 3. To analyze the component composition of the essential oil of leaves and flowers of Crataegus monogyna L. using chromato-mass spectrometric method

\begin{tabular}{l}
$\begin{array}{c}\text { Stage 4. Based on the obtained results, substantiate the prospects of } \\
\text { using leaves and flowers of Crataegus monogyna } \mathrm{L} \text {. as sources of } \\
\text { biologically active substances with antimicrobial, antifungal and } \\
\text { bactericidal action. }\end{array}$ \\
\hline
\end{tabular}

Fig. 1. The stages of the research of the component composition of the essential oil of leaves and flowers of Crataegus monogyna $\mathrm{L}$.

\section{Materials and methods}

For the study the raw materials Crataegus monogyna L. collected in the western region of Ukraine were used. The leaves were harvested in September 2019, the flowers - in the budding phase in May 2019. Species affiliation was determined with the advice of a senior researcher at the Botanical Garden of the National University M. N. Karazina Shatrovska V. I.

To obtain the essential oil, a portion $(60.0 \mathrm{~g})$ of crushed herbal drugs (leaves and flowers of Crataegus monogyna L.) was placed separately in a 11 flask, $300 \mathrm{ml}$ of water was added. The graduated receiver was fixed in the flask and connected to the steam tube. Distillation was performed for 2 hours [15].

The yield of essential oil $(X, \%)$ in terms of absolutely dry herbal drugs was calculated by the formula:

$$
x=\frac{V \cdot 100 \cdot 100}{m \cdot(100-W)},
$$

where $V$ - is the volume of essential oil, $\mathrm{ml} ; \mathrm{m}$ - is the mass of herbal drugs materials, $\mathrm{g} ; W-$ loss in weight during drying of herbal drugs, $\%$.

In order to expand the information on the physicochemical properties of the essential oil obtained from the flowers and leaves of Crataegus monogyna L., we have determined their acid numbers. To determine the acid number, a pharmacopeial method was used using ethanol and an indicator in recalculate on the weight of the obtained essential oil [15]. To do this, a portion of the essential oil of the leaves $(1 \mathrm{~g})$ and the essential oil of the flowers $(1 \mathrm{~g})$ was dissolved in $5 \mathrm{ml}$ of ethanol neutralized where $n$ - is the amount of potassium hydroxide solution $(0.1 \mathrm{~mol} / \mathrm{l})$, which used to the titration, $\mathrm{ml} ; m$ - weight of the sample, $\mathrm{g} ; 5.61$ - the amount of potassium hydroxide contained in $1 \mathrm{ml}$ of solution $(0.1 \mathrm{~mol} / \mathrm{l}), \mathrm{mg}$.

To determine the component composition of the essential oil of leaves and flowers of Crataegus monogyna L. a portion of herbal drugs $(5 \mathrm{~g})$ was placed in a vial of $20 \mathrm{ml}$, added an internal standard - tridecane. $10 \mathrm{ml}$ of water was added to the sample and volatile compounds of the sample were distilled off with steam for 2 hours using an air-cooled reflux condenser [16]. In the distillation process, volatile compounds are adsorbed on the inner surface of the reflux condenser.

The adsorbed compounds were washed after cooling the system by slowly adding $3 \mathrm{ml}$ of particularly pure pentane to a $10 \mathrm{ml}$ dry vial. The wash was concentrated by purging $(100 \mathrm{~mL} / \mathrm{min})$ with particularly pure nitrogen to a final extract volume of $10 \mu \mathrm{l}$, which was completely removed by a chromatographic syringe [17]. Further concentration of the sample was performed in the syringe to a volume of $2 \mu \mathrm{l}$. The introduction of the sample into the chromatographic column was performed in splitless mode (without flow separation), which allowed to enter the sample without loss on division and increase the sensitivity of the chromatographic method. The sample injection rate is $1.2 \mathrm{ml} / \mathrm{min}$ for 0.2 minutes. Chromatography conditions: Agilent Technologies 6890 chromatograph with mass spectrometric detector 5973; capillary chromatographic column DB-5 ext. diam. $0.25 \mathrm{~mm}$ and $30 \mathrm{~m}$ long; carrier gas velocity (helium) $1.2 \mathrm{ml} / \mathrm{min}$; temperature of the sample heater - 250 degrees; the temperature of the thermostat is programmed from 50 to 320 degrees with a speed of 4 degrees $/ \mathrm{min}$. To identify the components the NIST05 and WILEY 2007 mass spectrum libraries with a total number of spectra of more than 470,000 in combination with the AMDIS and NIST identification programs were used. The internal standard method was used for quantitative calculations.

The calculation of the content of components was performed according to the formula:

\section{$\mathrm{C}=K 1 \cdot K 2$,}

where $K 1=P 1 / P 2$ ( $\mathrm{P} 1$ - peak area of the test compound, $P 2$ - peak area of the standard); $K 2=50 / M$ (50 is the 
weight of the internal standard $(\mu \mathrm{g})$ entered in the sample, $M-$ is the sample weight $(\mathrm{g}))$.

\section{Results}

The quantitative content of essential oil in the flowers of Crataegus monogyna L. in terms of absolutely dry herbal drugs was $0.15 \pm 0.02 \%$, leaves $-0.11 \pm 0.03 \%$. The obtained essential oil of Crataegus monogyna L. flowers is a yellowish, transparent, oily liquid with an unpleasant odour; leaves - greenish-yellow, clear, oily liquid. Both oils are readily soluble in $96 \%$ ethanol and chloroform. For the essential oil of flowers, the acid number is 1.21 , the leaves -1.01 .

Gas chromatograms of the components of essential oils of flowers and leaves of Crataegus monogyna L. are shown in Fig. 2, 3.

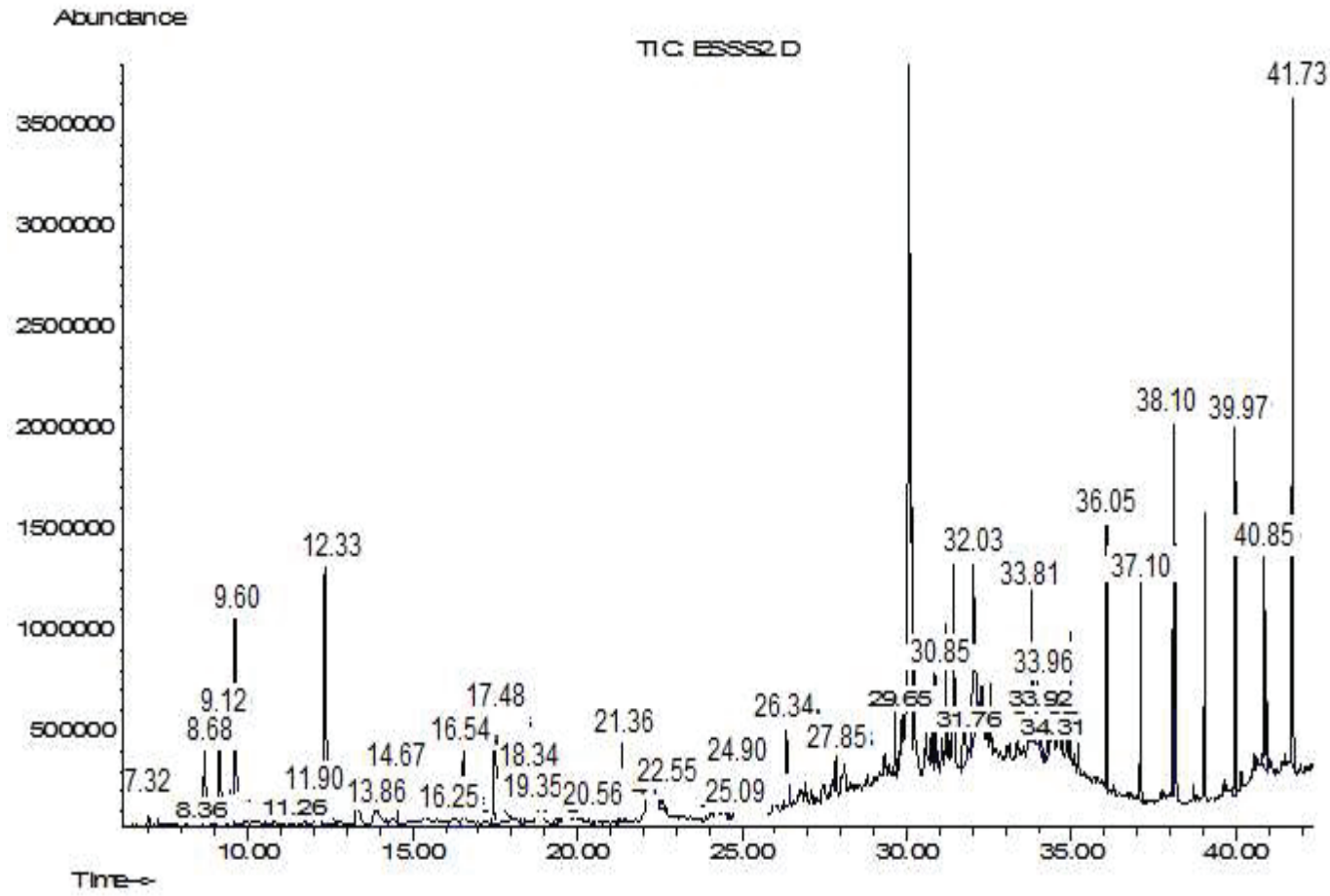

Fig. 3. Gas chromatogram of the components of the essential oil of leaves Crataegus monogyna L.

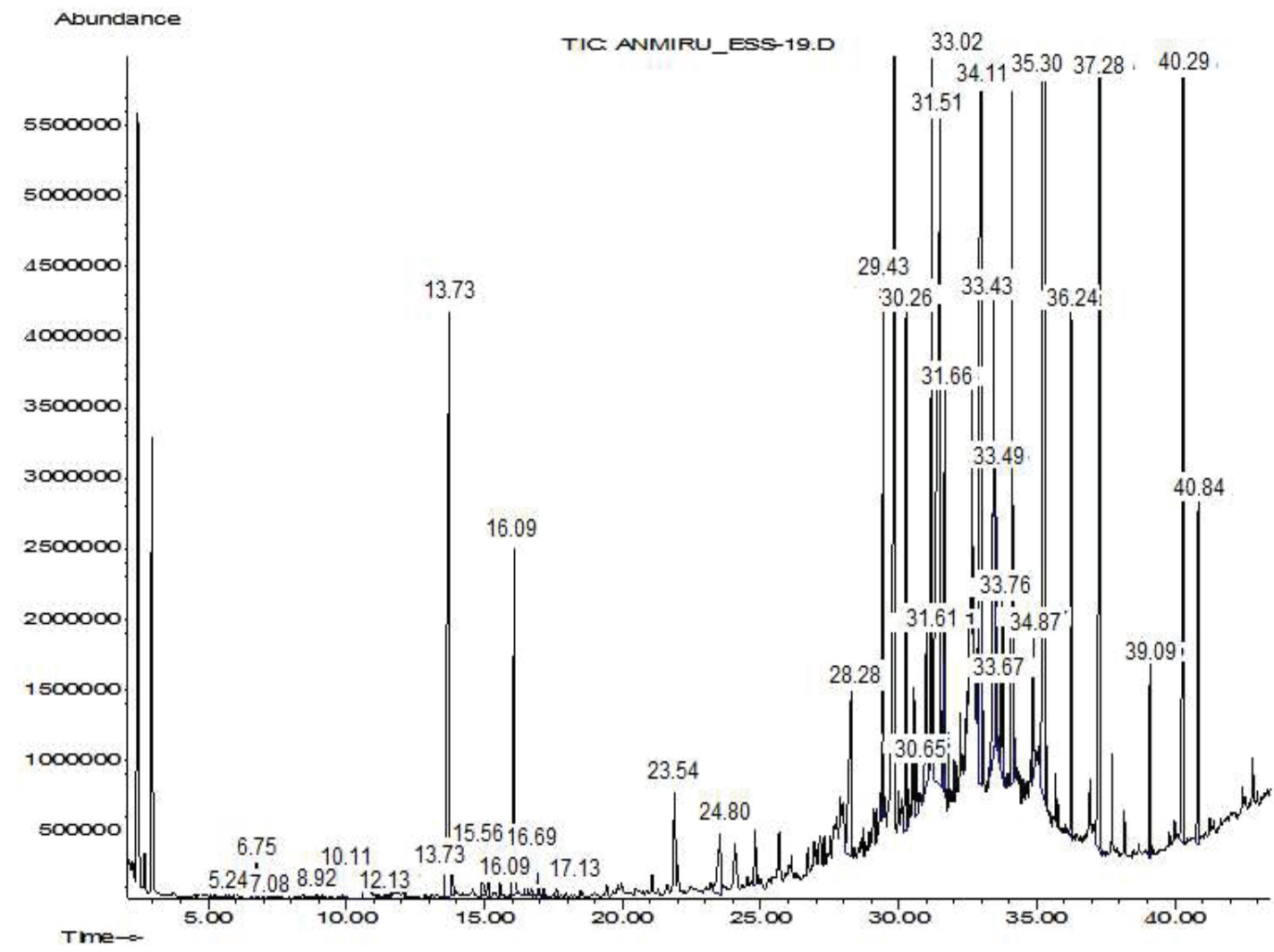

Fig. 2. Gas chromatogram of the components of the essential oil of flowers Crataegus monogyna L. 
In the essential oil of Crataegus monogyna L. flowers, 37 compounds were identified (Table 1), leaves 33 (Table 2). Flower essential oil monoterpenoids are represented by $\alpha$-pinene, limonene, 1,8-cineole, $\gamma$-terpinene, $\alpha$-terpineol, terpinene- 4 -ol and make up $0.44 \%$ of the total content; aromatic compounds - $p$-cymene, $\beta$-phenylethyl alcohol, anise aldehyde, methoxy-4-vinylphenol, eugenol, equal to $12.61 \%$ of the amount; triterpenoids - squalene $7.17 \%$. Also, in the essential oil of flowers indole is found $0.39 \%$ - a nitrogen-containing compound, which probably gives the essential oil of flowers an unpleasant, characteristic odour.

In essential oil of the leaves of Crataegus monogyna L. identified monoterpenoids and their derivatives as trans-linalool oxide, cis-linalool oxide, linalool, nerol, geraniol, geranyl acetone, $p$-ment-1-en-8-ol, total the amount was $37.80 \%$, dominated by linalool $(7.47 \%)$ and geraniol (9.78\%), p-ment-1-en-8-ol (10.61\%); aromatic compounds $(10.25 \%)$ - benzacetaldehyde, trans-ocimen, eugenol, lilac aldehyde, 4-vinyl-2-methoxyphenol, benzophenone, among which eugenol dominates $(7.48 \%)$; norterpenoids (3.62\%) - $\beta$-damaskenone, $\alpha$-ionone, $\beta$-ionone, $\beta$-ionone-5,6-epoxide; sesquiterpenoids and their derivatives $(4.02 \%)-\alpha$-farnesene, nerolidol, caryophyllene oxide, bisabolol oxide; diterpenoids are represented by phytol (2.17\%); triterpenoids - squalene (5.08\%). As can be seen from Table 2, a wider range of volatile compounds was identified in the essential oil of the leaves compared to the essential oil of the flowers.

The most pharmacologically valuable compounds identified in the essential oil of leaves and flowers of Crataegus monogyna L. are 1,8-cineole, linalool, geraniol, eugenol, bisabolol oxide, $\alpha$-pinene, squalene and nerol.

Other compounds identified in the essential oil of leaves and flowers of Crataegus monogyna L. are represented by higher alcohols, aldehydes, ketones.

Table 1

Component composition of essential oil of flowers Crataegus monogyna L.

\begin{tabular}{|c|c|c|c|}
\hline $\mathrm{N}$ & Compound & Retention time, min & Content, $\%$ of the amount \\
\hline 1 & 2 & 3 & 4 \\
\hline 1 & $\alpha$-Pinene & 5.24 & 0.06 \\
\hline 2 & Caproic acid & 5.7 & 0.10 \\
\hline 3 & $p$-Cymene & 6.54 & 0.03 \\
\hline 4 & Limonene & 6.64 & 1.90 \\
\hline 5 & 1,8-Cineole & 6.75 & 0.06 \\
\hline 6 & Phenylacetaldehyde & 7.08 & 0.07 \\
\hline 7 & $\gamma$-Terpinene & 7.5 & 0.04 \\
\hline 8 & Nonanal & 8.92 & 0.05 \\
\hline 9 & $\beta$-Phenylethyl alcohol & 10.11 & 1.69 \\
\hline 10 & Terpinene-4-ol & 11.16 & 0.04 \\
\hline 11 & Caprylic acid & 11.49 & 0.06 \\
\hline 12 & $\alpha$-Terpineol & 11.65 & 0.05 \\
\hline 13 & Decanal & 12.13 & 0.12 \\
\hline 14 & Anise aldehyde & 13.73 & 7.44 \\
\hline 15 & Indole & 14.9 & 0.39 \\
\hline 16 & 3-Methoxy-4-vinylphenol & 15.56 & 0.11 \\
\hline 17 & 2-Methoxy-4-vinylphenol & 16.09 & 3.27 \\
\hline 18 & 5-Pentyl-2 (5H) -furanone & 16.51 & 0.35 \\
\hline 19 & $\alpha$-Terpinyl acetate & 16.69 & 0.08 \\
\hline 20 & Eugenol & 16.95 & 0.10 \\
\hline 21 & $\gamma$-Nonalacton & 17.13 & 0.14 \\
\hline 22 & Lauric acid & 23.54 & 1.00 \\
\hline 23 & Benzophenone & 24.80 & 0.46 \\
\hline 24 & Myristic acid & 28.28 & 2.30 \\
\hline 25 & Hexahydropharnesylacetone & 29.43 & 2.72 \\
\hline 26 & Nonadecan & 30.26 & 2.68 \\
\hline 27 & Methyl palmitate & 30.65 & 0.34 \\
\hline 28 & Eicosan & 31.66 & 1.82 \\
\hline 29 & Heneicozan & 33.02 & 21.79 \\
\hline 30 & Docozan & 34.11 & 4.33 \\
\hline 31 & Tricozen-1 & 34.86 & 0.81 \\
\hline 32 & Tricosane & 35.3 & 25.08 \\
\hline 33 & Tetracosan & 36.24 & 2.35 \\
\hline 34 & Pentacosan & 37.28 & 10.03 \\
\hline 35 & Heptacosan & 39.09 & 0.89 \\
\hline 36 & Squalene & 40.28 & 7.18 \\
\hline 37 & Nonacosan & 40.84 & 1.73 \\
\hline
\end{tabular}


Table 2

Component composition of essential oil of leaves Crataegus monogyna L.

\begin{tabular}{|c|c|c|c|}
\hline $\mathrm{N}$ & Compound & Retention time, $\min$ & Content, $\%$ of the amount \\
\hline 1 & 2 & 3 & 4 \\
\hline 1 & Benzacetaldehyde & 7.32 & 0.96 \\
\hline 2 & trans-Ocimen & 8.36 & 0.05 \\
\hline 3 & trans-Linalool oxide & 8.68 & 2.76 \\
\hline 4 & cis-Linalool oxide & 9.12 & 4.62 \\
\hline 5 & Linalool & 9.59 & 7.48 \\
\hline 6 & Lilac aldehyde A & 10.52 & 0.17 \\
\hline 7 & Lilac aldehyde $\mathrm{C}$ & 10.79 & 0.41 \\
\hline 8 & Lilac aldehyde D & 11.26 & 0.17 \\
\hline 9 & Hepten-4-ol & 11.90 & 1.37 \\
\hline 10 & $p$-Ment-1-en-8-ol & 12.33 & 10.61 \\
\hline 11 & Nerol & 13.86 & 2.57 \\
\hline 12 & Geraniol & 14.67 & 9.79 \\
\hline 13 & 4-Vinyl-2-methoxyphenol & 16.25 & 1.01 \\
\hline 14 & Eugenol & 17.47 & 7.49 \\
\hline 15 & $\beta$-Damascenon & 18.34 & 0.40 \\
\hline 16 & Dodecanal & 19.35 & 0.24 \\
\hline 17 & Geranyl acetone & 20.56 & 0.21 \\
\hline 18 & $\alpha$-Ionone & 21.31 & 0.38 \\
\hline 19 & $\beta$-Ionone-5,6-epoxide & 21.356 & 2.31 \\
\hline 20 & $\beta$-Ionone & 21.41 & 0.55 \\
\hline 21 & $\alpha$-Farnesene & 22.55 & 0.71 \\
\hline 22 & Nerolidol & 24.57 & 0.25 \\
\hline 23 & Caryophyllene oxide & 24.82 & 0.51 \\
\hline 24 & Benzophenone & 25.08 & 0.45 \\
\hline 25 & Bisabolol oxide & 26.34 & 2.57 \\
\hline 26 & Tetradecanal & 27.84 & 0.53 \\
\hline 27 & Phytol & 33.80 & 2.18 \\
\hline 28 & Tricosan & 36.05 & 4.41 \\
\hline 29 & Pentacosan & 37.10 & 3.40 \\
\hline 30 & Hexacosan & 38.10 & 6.32 \\
\hline 31 & Heptacosan & 39.96 & 6.12 \\
\hline 32 & Squalene & 40.84 & 5.08 \\
\hline 33 & Nonacosan & 41.72 & 13.82 \\
\hline
\end{tabular}

\section{Discussion of research results}

For the first time the essential oil of leaves and flowers of Crataegus monogyna L. from Ukrainian flora was obtained and its component composition was established. It was found that the quantitative content and composition of the components of essential oils of flowers and leaves of Crataegus monogyna L. are differs significantly.

It has been scientifically proven that the monocyclic monoterpenoid 1,8-cineole in combination with the bicyclic monoterpenoid $\alpha$-pinene, identified in the essential oil of flowers, can have antimicrobial, fungicidal, antistaphylococcal action [18].

Due to the high content of geraniol and eugenol, the essential oil of Crataegus monogyna L. leaves can have anti-inflammatory and antiseptic effects; linalool and its oxides - bactericidal; bisabolol oxide - anti-inflammatory, antimicrobial, epithelializing [19, 20].

Squalene, which is found in both essential oils, is readily easily absorbed by the skin due to the fact that it is directly a protective component of human skin, thus can accelerate the penetration of drugs through the skin, has a regenerating, anti-inflammatory effect.

Given the above properties of the compounds that are part of the essential oils of leaves and flowers of $\mathrm{Cra}$ taegus monogyna L., they can be used in the future as components of antimicrobial drugs.

Due to its chemical composition, the essential oil of Crataegus monogyna L. flowers can be used in combination drugs to correct skin diseases caused by Staphylococcus aureus; essential oil of leaves - for the treatment of dermatitis and eczema, in the etiology of which the causative agents are members of the genus Candida.

Research limitations. Since the chromato-mass spectrometric study of the component composition of essential oils identified the compounds by comparing the obtained spectra with an automatic database library, the compounds whose spectra were in the register were identified. Therefore, not all compounds for which quantita- 
tive content was determined by this method could be identified.

Prospects for further research. To create new drugs based on the essential oil of leaves and flowers of Crataegus monogyna L., it is advisable to study its antimicrobial activity, establish basic quality indicators and standardize the resulting substance.

\section{Conclusions}

Essential oils of leaves and flowers of Crataegus monogyna L. from Ukrainian flora were obtained and their quantitative content and acid number were determined. The component composition of the essential oil was determined by chromato-mass spectrometric method, in which 37 compounds were identified, 10 of which were identified for the first time. The main components of the essential oil of leaves and flowers are: trans-linalool oxide, cis-linalool oxide, linalool, nerol, geraniol, geranyl acetone, p-ment-1-en-8-ol, $\alpha$-pinene, limonene, 1,8-cineole $\gamma$ methoxyphenol, benzophenone, $\beta$-damaskenone, $\alpha$-ionone, $\beta$-ionone, $\beta$-ionone-5,6-epoxide, $\alpha$-farnesene, nerolidol, caryophyllene oxide, bisabolol oxide, phytol, squalene.
Essential oils of leaves and flowers of Crataegus monogyna L. are a promising substance for further research and implementation and contain a wide range of biologically active compounds belonging to monoterpenoids, aromatic compounds, norterpenoids, sesquiterpenoids, diterpenoids and triterpenoids.

\section{Conflict of interests}

The authors declare that they have no conflicts of interest.

\section{Financing}

The study is a fragment of the scientific work of the National University of Pharmacy "Pharmacognostic study of medicinal plant raw materials and the development of pharmacotherapeutic agents based on them" (state registration number 0114U000946).

\section{Acknowledgements}

We are grateful to the senior researcher of the Botanical Garden of the V. N. Karazin Kharkiv National University Shatrovskaya V. I. for botanical evaluation and identification of the studied plant and raw materials.

\section{References}

1. Derzhavna Farmakopeia Ukrainy (2016). Kharkiv: Derzhavne pidpryiemstvo «Ukrainskyi naukovyi farmakopeinyi tsentr yakosti likarskykh zasobiv», 360 .

2. European Pharmacopoeia. Vol. 1 (2010). Strasbourg: Council of Europe, 3307.

3. Rababa'h, A. M., Al Yacoub, O. N., El-Elimat, T., Rabab'ah, M., Altarabsheh, S., Deo, S. et. al. (2020). The effect of hawthorn flower and leaf extract (Crataegus Spp.) on cardiac hemostasis and oxidative parameters in Sprague Dawley rats. Heliyon, 6 (8). doi: http://doi.org/10.1016/j.heliyon.2020.e04617

4. Sydora, N. V., Kovaleva, A. M., Iakovenko, V. K. (2016). Phytochemical research of Crataegus submollis Sarg. leaves lipophilic complex and study of its antibacterial activity. Der Pharmacia Lettre, 8 (21), 19-23.

5. Halver, J., Wenzel, K., Sendker, J., Carrillo García, C., Erdelmeier, C. A. J., Willems, E. et. al. (2019). Crataegus Extract WS ${ }_{1442}$ Stimulates Cardiomyogenesis and Angiogenesis From Stem Cells: A Possible New Pharmacology for Hawthorn? Frontiers in Pharmacology, 10. doi: http://doi.org/10.3389/fphar.2019.01357

6. Wang, X., Liang, Y., Shi, J., Zhu, H., Bleske, B. (2018). Crataegus Special Extract WS 1442 Effects on eNOS and microRNA 155. Planta Medica, 84 (15), 1094-1100. doi: http://doi.org/10.1055/a-0601-7083

7. Khokhlova, K. O., Zdoryk, O. A., Sydora, N. V., Shatrovska, V. I. (2019). Chromatographic Profiles Analysis of Fruits of Crataegus L. Genus by High-Performance Thin-Layer Chromatography. European Pharmaceutical Journal, 66 (2), 45-51. doi: http://doi.org/10.2478/afpuc-2019-0020

8. Abuashwashi, M. A., Palomino, O. M., Gómez-Serranillos, M. P. (2016). Geographic origin influences the phenolic composition and antioxidant potential of wildCrataegus monogynafrom Spain. Pharmaceutical Biology, 54 (11), 2708-2713. doi: http:// doi.org/10.1080/13880209.2016.1179769

9. Belabdelli, F., Bekhti, N., Piras, A., Benhafsa, F. M., Ilham, M., Adil, S., Anes, L. (2021). Chemical composition, antioxidant and antibacterial activity of Crataegus monogyna leaves' extracts. Natural Product Research, 1-6. doi: http://doi.org/10.1080/147864 19.2021.1958215

10. Lis, M., Szczypka, M., Suszko-Pawłowska, A., Sokół-Łętowska, A., Kucharska, A., Obmińska-Mrukowicz, B. (2019). Hawthorn (Crataegus monogyna) Phenolic Extract Modulates Lymphocyte Subsets and Humoral Immune Response in Mice. Planta Medica, 86 (2), 160-168. doi: http://doi.org/10.1055/a-1045-5437

11. Rababa'h, A. M., Altarabsheh, S. E., Haddad, O., Deo, S. V., Obeidat, Y., Al-Azzam, S. (2016). Hawthorn Herb Increases the Risk of Bleeding after Cardiac Surgery: An Evidence-Based Approach. The Heart Surgery Forum, 19 (4), 175-179. doi: http:// doi.org/10.1532/hsf.1570

12. Kuhn, T., Jancso, B., Ruprecht, E. (2021). Hawthorn (Crataegus L.) Taxa and their hybrids in North-Western Romania: a recommendation for national identification keys based on morphometric analyses. Contribuţii Botanice, 55, 7-26. doi: http:// doi.org/10.24193/contrib.bot.55.1

13. Phipps, J. B. (2016). Studies in Mespilus, Crataegus, and $\times$ Crataemespilus (Rosaceae), II. The academic and folk taxonomy of the medlar, Mespilus germanica, and hawthorns, Crataegus (Rosaceae). Phytotaxa, 260 (1), 25-35. doi: http://doi.org/10.11646/ phytotaxa.260.1.3 
14. Sydora, N. (2018). Morphological and taxonomic study of oxyacanthae Zbl. section of crataegus L. genus by vegetative characteristics. ScienceRise: Pharmaceutical Science, 1 (11), 36-41. doi: http://doi.org/10.15587/2519-4852.2018.124432

15. Derzhavna Farmakopeia Ukrainy. Vol. 1 (2015). Kharkiv: Derzhavne pidpryiemstvo «Ukrainskyi naukovyi farmakopeinyi tsentr yakosti likarskykh zasobiv», 1128.

16. Chernogorod, L. B., Vinogradov, B. A. (2006). Efirnye masla nekotorykh vidov roda Achillea L., soderzhaschie fragranol. Rastitelnye resursy, 42 (2), 61-68.

17. Sydora, N. V., Kovalova, A. M. (2016). Gas-chromatographic-mass spectrometric studies the volatile compounds and organic acids the leaves of Crataegus macracantha Loud. American Journal of Science and Technologies, 3 (1 (21)), $1041-1045$.

18. Elshafie, H. S., Camele, I. (2017). An Overview of the Biological Effects of Some Mediterranean Essential Oils on Human Health. BioMed Research International, 2017, 1-14. doi: http://doi.org/10.1155/2017/9268468

19. Aljaafari, M. N., AlAli, A. O., Baqais, L., Alqubaisy, M., AlAli, M., Molouki, A. et. al. (2021). An Overview of the Potential Therapeutic Applications of Essential Oils. Molecules, 26 (3), 628. doi: http://doi.org/10.3390/molecules26030628

20. Jugreet, B. S., Mahomoodally, M. F. (2020). Pharmacological Properties of Essential Oil Constituents and their Mechanisms of Action. Plant-Derived Bioactives. Singapore: Springer, 387-415. doi: http://doi.org/10.1007/978-981-15-2361-8_18

Received date 22.09.2021

Accepted date 16.12.2021

Published date 30.12.2021

Natalia Sydora, Doctor of Pharmaceutical Science, Associate Professor, Department of Pharmacognosy, National University of Pharmacy, Pushkinska str., 53, Kharkiv, Ukraine, 61002

Olena Konovalova, Doctor of Pharmaceutical Science, Professor, Department of Pharmaceutical and Biological Chemistry, Pharmacognosy, Private Higher Educational Establishment "Kyiv Medical University", Boryspilska str., 2, Kyiv, Ukraine, 02099

Svetlana Zuikina, Doctor of Pharmaceutical Science, Associate Professor, Department of Pharmaceutical Technology of Drugs, National University of Pharmacy, Pushkinska str., 53, Kharkiv, Ukraine, 61002

Kateryna Semchenko, Doctor of Pharmaceutical Science, Associate Professor, Department of Pharmaceutical Technology of Drugs, National University of Pharmacy, Pushkinska str., 53, Kharkiv, Ukraine, 61002

Anna Rudnyk, PhD, Associated Professor, Department of Pharmacognosy, Pharmacology and Botany, Zaporizhzhia State Medical University, Maiakovskyi ave., 26, Zaporizhzhia, Ukraine, 69035

Iryna Hurtovenko, PhD, Associate Professor, Department of Pharmaceutical and Biological Chemistry, Pharmacognosy, Private Higher Educational Establishment "Kyiv Medical University”, Boryspilska str., 2, Kyiv, Ukraine, 02099

*Corresponding author: Natalia Sydora,e-mail: sydora2005@gmail.com 